\title{
Kafâ'ah Contextualization In An Effort To Form Harmonious Family In The Modern Era: An Analysis Of Fazlur Rahman's Double Movement Theory
}

\author{
Mokhammad Samson Fajar ${ }^{1}$, Faris al Badr²
}

\begin{abstract}
Kafầah Contextualization In An Effort To Form Harmonious Family In The Modern Era: An Analysis Of Fazlur Rabman's Double Movement Theory. Kafâ'ah is a marriage law that has relatively little attention from Islamic jurists. This is because kafâa $a$ is less adaptable to changes in people's lives. Because kafâ'ah is identical with the Arab cultural heritage before Islam. But factually this kafấah is still a legacy in the books of the fuqaha'. This research is focused on revealing the relevance of the concept of the kafáah of the fuqaha' with the changing times of the modern era. As well as how to contextualize the concept of kafâa $a h$ in this modern era so that it truly becomes a path to family harmony. In uncovering the problem, the double movement theory or Fadzlurrahman dual interpretation is used, in which this interpretation becomes the knife of analysis by revealing how the current condition of the kafâa $a$ is then drawn to the kafâah of the past and how the response of the Qur'an and the Sunnah. Then the moral values of the Qur'an and the Sunnah are taken using reasoning ratios so that conclusions can be drawn in accordance with current needs. The conclusion of this research is that the concept of kafâah in the book of fiqh is not relevant to the needs of this modern era, where kafâa $a$ in the modern era is more interpreted in terms of equality and ability (competence) to get married, which is different from the kafâa of the past which is more nuanced feudalistic.
\end{abstract}

Keywords: kafầah, modern era, harmonious, Fazlur Rahman

\begin{abstract}
Abstrak: Kontekstualisasi Kafâ'ah dalam Upaya Membentuk Keluarga Harmonis di Era Modern: Analisis Double Movement Fazlur Rabman. Kafâ'ah adalah hukum perkawinan yang memiliki perhatian relatif sedikit dari para ahli hukum Islam. Karena kafấah kurang bisa beradaptasi dengan perubahan dalam kehidupan masyarakat. Kafẩah identik dengan warisan budaya Arab sebelum Islam. Namun sebenarnya, kafầahmasih menjadi warisan dalam kitabkitab para fukaha. Penelitian ini difokuskan untuk mengungkap relevansi konsep kafầah para fukaha dengan perubahan zaman di era modern. Sekaligus mengkontekstualisasikan konsep kafâah di era modern, agar benar-benar menjadi jalan menuju keharmonisan keluarga. Dalam mengungkap permasalahan tersebut, digunakan teori gerakan ganda atau tafsir ganda Fadzlurrahman. Tafsir tersebut menjadi pisau analisis dengan mengungkap kondisi kafâa saat ini kemudian ditarik ke kafâa hasa lalu dan tanggapan Alquran dan Sunnah. Kemudian diambil nilai moral Alquran dan Sunnah dengan menggunakan nalar sehingga kesimpulan yang diambil dapat sesuai dengan kebutuhan saat ini. Kesimpulan dari penelitian ini adalah
\end{abstract}

${ }^{1}$ Faculty of Islamic Studies, Muhammadiyah University of Metro

${ }^{2}$ Dekan Passion International University for Sciences, Arts and Development, America

E-mail: ${ }^{1}$ ibnuummi@gmail.com, ${ }^{2}$ farislabadr@gmail.com 
bahwa konsep kafẩah dalam kitab fikih tidak relevan dengan kebutuhan jaman modern ini. Kafẩah di jaman modern lebih dimaknai dalam pengertian persamaan dan kemampuan (kompetensi) untuk menikah, berbeda dengan kafẩah masa lalu yang lebih bernuansa feodalistik.

Kata Kunci: kafẩah, era modern, harmonis, Fazlur Rahman

\section{Introduction}

Allah creates mankind in pairs, man and woman. From the couple, Allah composes the couple to be a community then nations (syu'ub), tribes ( $q a b \hat{a} i l)$ so that there is a harmonious social interaction. They will know each other, understand, love and eventually lead to a good social order fully of peace and love. Allah says:

"And Allah created you from dust, then from a sperm-drop; then He made you mates. And no female conceives nor does she give birth except with His knowledge. And no aged person is granted (additional) life nor is his lifespan lessened but that it is in a register. Indeed, that for Allah is easy. (Faatir:11)"

In another verse, Allah says:

"O mankind, indeed We have created you from male and female and made you peoples and tribes that you may know one another. Indeed, the most noble of you in the sight of Allah is the most righteous of you. Indeed, Allah is Knowing and Acquainted. (Al-Hujuraat: 13).

Allah created human being in pairs for not only as partners of sexes, but as well to contain a very deeply psychological conception. It can be seen in another verse, the word of "azwâja" is translated as a wife who may calm the man's soul. In surah Ar-Ruum, verse 21. Thus, what it is meant by the word of couple above is in which conformities in human beings. When the conformities are met in a person soul it will produce serenity (al-sakinah) in a family life.

The word of kafâah is known in marriage law. Ibn Mandzur defines, $k a f a ̂ a h$ as a state of balance. The word of kafâah originally derived from al-kufü means al-musâwi (balance). When it is connected to the word of marriage, kafấah means the balances between the bride and the bride 
groom, in term of their social status (hasab), belief/religion (al-dîn), offspring (nasab) and the likes. ${ }^{1}$

Meanswhile, based on the fuqaha's terminology, kafâah is defined as similarity in social matters, which is later on may create happiness and prosperity living in a family, and it will be able to remove distress. ${ }^{2}$ However, the various qualifications offered in this purpose, there is only a qualification agreed by fuqaha is that religious qualification (dîn); religion (millah), righteous and goodness. Thus, other qualifications, such as elements of independence, offspring (nasab), father's religion, free from physical diseases and own psychiatric health. Even though, some Islamic Scholars still have different perspectives of them, those who acknowledge them as the elements of kafâah, some who not admitted the elements. ${ }^{3}$

In other words, Muhammad Abu Zahrah defines kafấah as the balance between husband and wife with certain conditions in which, they will together be able to face any difficulties in lives. So kafấah can be articulated as a balance or equality between husband and wife. ${ }^{4}$ The elements of kafâah are still being debated by scholars.

The purpose of kafâah in marriage is the equality of conditions between husband and wife, in equal position. The husband has equal position in the community with his wife, in terms of the characters and wealths. Similarity and compatibility between husband and wife will lead to their household welfares, and the way they can avoid from every bad lucks. It has been described by the experts of Islamic jurisprudence. ${ }^{5}$

Shaykh Zainudin bin Abdul Aziz al-Malibarry, in his book Fathul Mu'în, views the kafâ'ah as a very essential (mu'tabarah) in marriage,

${ }^{1}$ Jamal al-din Muhammad ibnu Mukarram al-Ansari al-Manzur, Lisan Al-Arabi (Mesir: Dar al Misriya, t.t), p. 134.

${ }^{2}$ Khoiruddin Nasution, Hukum Perkawinan I (Yogyakarta: Academia, 2004), p. 217.

${ }^{3}$ Mustafa al-Sibầî, Sharh Qânun Al-Ahwâl al-Shakhsîyah (Damaskus: TNP, 1385), p. 170.

${ }^{4}$ Muhammad Abu Zahrah, Al-Ahwâl al-Shakhsîyah (Mesir: Dâral-Fikr wa al-'Arabî, 1369), p. 156.

${ }^{5}$ H.S.A Al-Hamdani, Risalah Nikah (Hukum Perkawinan Islam I), III (Jakarta: Pustaka Amani, 1989), p. 98. 
although it does not affect the validity of a contract. He further classifies social levels which are considered in kafâah. He mentions that there are several criteria for a husband and wife to be equal or at the same levels, including social status, moral views, religion, profession, and science. However, he said that assets or properties are not included in the criteria of kafẩah, as a property can disappear and will not make pride for those who maintain murûah (integrity). ${ }^{6}$

Kafâah is considered as an important part in marriage because it involves the survival of a married couple. Kafâah is a problem that is still debatable among the Islamic scholars (ulama) since long time ago. As the social status is not a distinctive matter in the principle of Islam, but the distinction has to make human beings easily to recognize and interact each other. The significant distinctive matter in Islam is the value of rightheous in his/her heart.

If it is seen from the historical aspect, kafâah as a law in marriage is very conditional with the conditions under which the law was first revealed. The kafâah was revealed in the old Arab society in which at that time still applied in their tribal system. Each tribe felt owning highest position compared to the others. So that, in a marriage the old Arabic bride must be equal in his position. And it is strictly not permissible to violate this tribal rules. So when there is a degree difference in the tribe, it will cause disharmony in the household. This is the author's hypothesis that the kafâah rules is very influenced by the condition of the society at that time. Whereas, the condition of society in Indonesia is different from Arab society, certainly sharia kafấah requires deeper and sharper interpretation, so that it becomes a new concept (in tajdîd framework) in the current modern era.

Factually, it cannot be denied that another kafấah factors also contribute to the formation of the family of sakinah mawaddah wa rahmah. However, these factors will relate to the conditions and circumstances of the surround community. Especially in this modern era, it is very

${ }^{6}$ Zainudin al-Malibary, Fathu Al-Mu’in (Beirut: Dar al-Ihya' al-Kitab al-'Arabiyah, t.t), p. 106. 
possible for various forms of changes in kafâah law, and even kafấah is very important in todays condition. As kafấah is stated as a marriage law in order to establish a harmonious family.

This research was focused on the marriage law (kafâah) in the modern era. Modern is a process in which everything is open and free, both information and technology, between one country and another there is no barrier that prevents it. The free flow of goods, the flow of services, freedom of investment, freedom of labor, freedom of capital and moral freedom are real. ${ }^{7}$

Modern is characterized by a total transformation from traditional or pre-modern life in terms of technology and social organization, towards economic and political patterns related to Western countries. ${ }^{8}$ The general characteristics of modernization concern with the sociodemographic aspects of society and the socio-demographic aspects are described in terms of social mobility, a process in which the socio-economic and psychological aspects of society begin to show opportunities. The opportunities for new patterns through visualization and behavior patterns, which manifest in aspects of modern life such as mechanization, regular mass media, urbanization, increasing income per capita and so on. ${ }^{?}$

As the more modern life that people have todays, especifically the Islamic ummah, it automatically greatly influences the Islamic law. The law in this context is kafâah. Is the kafâah in the modern era is still the same as the conception of the kafâah as stated in fiqh or has it changed either interpretatively or perhaps in number. Even in depth whether the kafâah becomes the dominant factor in various cases of family disharmony, and which kafầah elements are the most influential in this modern era.

${ }^{7}$ Rachman Syarief, Kepemimpinan Transformasional Dan "U Theory" Di Pendidikan Tinggi Dalam Menyongsong Pasar Bebas Asean, (Metro: Universitas Muhammadiyah Metro, 2014).

${ }^{8}$ Soerjono Soekanto, Sosiologi Suatu Pengantar, V (Jakarta: CV. Rajawali, 1985), p. 357.

9 S.N. Eisentadt, Modernization: Protest and Change (Prentice Hall Inc,Englewood Cliffs, 1966), p. 2. 
Kafâah or kufü which very rarely get attention of Muslim scholars and the Muslims themselves, when this law must deal with modernization it must be developed. The development of this law is not in the sense of changing the substance of Islamic sharia, but rather on the development of a conceptual and philosophical natures. So in the end, $k u f u$ ' becomes a legal theory which is very relevant to be developed practically in the modern era.

In the perspective of Islam, family harmony is called the sakinah family, a family that is fostered based on a legal marriage, able to fulfill the living physically and spiritually, spiritually and materially, capable of creating an atmosphere of mutual love, affection (mawaddah wa rahmah), in harmony, harmonious and balanced and able to instill and implement the values of faith, piety, pious deeds and noble morals in the family and community environment in accordance with the noble values of the Pancasila and the 1945 Constitution and in harmony with Islamic teachings. As mentioned in Qur'an Surrah Ar-Room verse 21:

"And of His signs is that He created for you from yourselves mates that you may find tranquility in them; and He placed between you affection and mercy. Indeed in that are signs for a people who give thought." (Ar-Room: 21)

A harmonious and qualified family is that a harmonious family that lives happily, orderly, disciplinary, respectively each other. It lives with a full of forgiveness, has virtue, has a good work ethic, easily help neighbors, own mutual respect, be obedient to worship, filial piety to parents, loves science and kill the free time by doing positive activities and capable to fulfill the basic family needs. ${ }^{10}$

Harmonious family will only be created if the happiness of one member is related to the happiness of the rest family members. Psychologically it can mean two things:

${ }^{10}$ Hasan Basri, Merawat Cinta Kasih (Yogyakarta: Pustaka Pelajar, 1996), p. 111. 
1. Achieving the wishes, goals and hopes of all family members.

2. As few conflicts as possible within each person and between individuals. ${ }^{11}$

A harmonious family is a family that is full of calm, serenity, affection, descent and continuity of generations of people, compassion and sacrifice, complementing and perfecting one another, and helping and cooperating with each other. ${ }^{12} \mathrm{~A}$ harmonious family or a happy family is when both partners respect, accept each other, respect each other, trust each other, and love each other.

Household harmony in the past era will certainly be very different from todays, when the standard era kafâah was able to be a factor of household harmony, then is it still able to present harmony in the modern era now? Therefore, the research in this dissertation will reveal some problems related to the concept of kafâah as a sub-system of family law when it has to deal with modernization, using the ijtihad rules approach so that it will give birth to a concept that is more relevant in accordance with the spirit of Islam "şalihun likulli zamân wa makân". ${ }^{13}$

In qualitative research the focus of the problem is often referred to as the research focus. The focus of the study is the subject matter chosen in this research. The focus of this research limit the study, meet the inclusion-exclusion criteria or enter-issue a new information obtained in the field.

In order to avoid the bias in this study, the researcher limit the research problem or determine the unit of analysis. ${ }^{14}$ The unit of analysis is something related to the focus / component being investigated, it can be in the form of individuals, groups, organizations, objects, regions and time with the focus of the problem. There are two units of analysis in

${ }^{11}$ Sarlito Wirawan Sarwono, Menuju Keluarga Bahagia 4 (Jakarta: Bhatara Karya Aksara, 1982), p. 2.

${ }^{12}$ Ali Qaimi, Menggapai Langit Masadenpan Anak (Bogor: Cahaya, 2002), p. 14.

${ }^{13}$ About modernization of Islamic law, see Abdul Qodir Zaelani, 'Pembaruan Hukum Keluarga: Kajian Atas Sudan - Indonesia', Al-'Adalah, 10.1 (2012), 331-342; 'Konsep Ta'aqquli Dan Ta’abbudi Dalam Konteks Hukum Keluarga Islam', Asas, 6.1 (2014) , 46-56.

${ }^{14}$ Imam Suprayogo dan Tobroni, Metodologi Penelitian Sosial-Agama (Bandung: PT Rosda Karya, 1998), p. 48. 
this study, namely, kafâah conceptions and time-related ones that are modern. In order to avoid the biased in studying this problem, the limitation of the problems have narrowed to the unit of the analysis, namely Contextualization and Relevance of kafấah in marriage with the ushul fiqh, sociological and anthropological approaches in realizing domestic harmony.

This research can formulate the problem "How is the contextualization of kafâah in Islamic Family Law in the Modern Era to create a harmonious family? with the formulation of the problem can be detailed in several research questions (research question). How is the relevance of kafâah in fiqh books with the complexity of the problems of the lives of the Ummah in the modern era? How is the contextualization of the concept of kafâah relevant to the life of the Islamic Ummah in the modern era?

The simple hypothesis in this study is that kafa'ah has been offered conceptually in the book of Islamic jurisprudence, and it requires contextualization, so that it will result to be more relevant and modern conceptions in the Islamic jurisprudence, which is in accordance with the needs of the Ummah (people). In conducting contextualization, the researcher implemented Fazlur Rahman's double movement theory as a research instrument to analyze the resulted data, to present applicative and relevant conclusions.

\section{Fadzlurrahman's Double movement Contextualization Theory}

Ijtihad as a custom in Islam is the most important concern in Fazlur Rahman's thoughts. He interprets the ijtihad as a freedom of responsible thought. Eventhough, it is better than understanding the Islamic religion (doctrines) by following the personal assumptions and analogies. The possibilities of conducting ijtihad will be opened when the matters are not contained in the Qur'an. ${ }^{15}$

${ }^{15}$ Abdul Manan, Reformasi Hukum Islam Di Indonesia (Jakarta: Raja Grafindo Persada, 2006), p. 207. 
According to Rahman, the interpretation which is able to accommodate intellectual demands and moral integrity is the interpretation that refers to historical criticism. Thus, the values and the spirit of the Qur'an and hadith can be achieved and understood. So the double movement interpretation theory may be emerged.

Rahman essentially develops a method of interpreting brought by the previous Islamic scholars, in which He thinks that the previous Islamic scholars are still unable to present a whole world view thoroughly, due to be more interpreting verse by verse. For instance, a muffasirin (interpreter) who interpret the verse of Qur'an in a thematic way but have not been able to show the integration of the meaning of the Qur'an or Sunnah, leads to a unified world understanding. Rahman names this methodology as Double Movement (double movement theory). ${ }^{16}$

The first step of the movement is that one must understand the meaning or aiming of a particular statement based on studying historical situations or problems which will further examine the general of macro situation within the constraints of society, religion, customs, infrastructure, even about the way of lives as a whole in Arabia. ${ }^{17}$ In other words, the mufassir (interpreter) understands the meaning of the Qur'an both micro and macro then takes the essence of the universal value of the Qur'an to be applied in life.

The second step of this movement is to generalize specific answers and express them as statements that have social moral goals filtered from specific verses in the context of socio-historical and rationes legis backgrounds that are often stated. This second movement seeks to find a moral ideas after the socio-socialist study then the moral ideas found its existence and becomes a living text in the regulation of Muslim lives. ${ }^{18}$

${ }^{16}$ Ahmad Syukri, 'Metodologi Tafsir Al-Qur'an Kontemporer dalam Pemikiran Fazlur Rahman', Kontekstualita: Jurnal Penelitian Sosial Keagamaan, 20.1 (2005), 37111.

${ }^{17}$ Fazlur Rahman, Islam and Modernity: Transformation of an Intelectual Tradition (Chicago \& London: The university of Chicago Press, 1982), p. 7.

${ }^{18}$ Edi Hermanto, 'Implementasi Teori Tafsir Gerak Ganda Fazlur Rahman Pada Buku Ajar Al-Qur'an Dan Hadist', An-Nida', 41.1 (2018), 31-49. 
The first movement of this theory essentially is to seek the understanding of the macro and micro context of the revelation process of the Qur'an. The aim is to construct the original meaning of revelation based on the social context of the prophet and the community who lived surroundings at that time. This process is related to traditional scientific concepts in the interpretation of the Qur'an, such as asbâb al-nuzĥl and nâsikh mansîkh. ${ }^{19}$

While the second movement is an attempt to apply the values and the principles which commonly exists in the context of the present reader of the Qur'an. This effort requires analysis relating to the social sciences and modern humanities science as an adequate knife of analysis. ${ }^{20}$

The Double Movement hermeneutics method is in line with the Qur'anic rules namely al-ibrah bi umûm al-lafd lâ bi khushûs al-sabab that is taking lessons or law from the generality of lafzh, not from the specificity of the cause. It is clearer that when a verse comes down because of a special reason while the general lafazh, then the law contained in the verse covers the cause and everything covered by the meaning of lafazh, since the Qur'an descends as general sharìah touches all people, becomes the benchmark/standard is the generality of the lafazh, not the specificity of the cause. ${ }^{21}$

\section{Implementation of Dual Motion Theory in Kafâ'ah}

In understanding the kafâah based on the theory of multiple motion interpretation must use the above principles in it. Therefore, in understanding kafa'ah in the first way, using reality, both social, natural, humanity, and religion as a source of interpretation, not solely on the text of the Qur'an and Hadith. Secondly, the conclusions built in the law of kafấah are systematized based on logical reasoning, not through the

${ }^{19}$ Fazlur Rahman, Kebangkitan Dan Pembaharuan Di Dalam Islam (Bandung: Pustaka, 2001), p. 17.

${ }^{20}$ Fazlur Rahman, Kebangkitan Dan Pembaharuan Di Dalam Islam.

${ }^{21}$ Jamalabdulaziz, 'Teori Gerak Ganda (Metode Baru Istinbdt Hukum Ala Fazlur Rahman)', Hermenia, 6.No. 2 (2007), 329-49. 
authority of certain texts, orthodoxy and ideologically. Thirdly, using the approach of sociology, anthropology, culture, and history in understanding the reality of the kafâah which is being interpreted. Fourthly, the purpose of interpretation is not to confirm the truth of the text but rather to emphasize the analysis and theoretical formulationa through scientific logic. ${ }^{22}$

\section{Kafa'ah and Its Historicity in Islamic Law}

\section{Definition of Kafâ'ah}

Kafâah is a term in marriage that rarely raised in-depth discussion, even being less attention by scientists. It is probably so small if it is taken as the theme of the discussion. So that, this thing is not being a concern by many Muslim intellectuals. Although, the theme of the kafâah is a small theme, in this article, the kafâah theme will get very large attention and become a theory that will have a big influence in developing the Islamic civilization, especially for the establishment of muslim families to be mawaddah warahmah.

Kafâ'ah comes from the word of al-kufü which means al-mitslu and al-nadzîr which means equality (equivalent). Whereas if al-kufü means al-mitslu wa al-nadzir also (equal to), it also means al-qâdir' ala al-'amal al-jadîr bih or the ability to carry out activities (qualified). If al-kaf' means musâwiyan li sya'in akhor which means to have something in common with others (social equality). So, when kafâah is idhôfah with al-zawâj (marriage), it means the equality between husband and wife or in matters of heredity, religion and social status and others. When it is based on al-alamal, it means the ability to carry out activities properly and correctly as per existing standards (qualification). ${ }^{23}$

In Lisân al-Arâb the word al-kafâah means counter, as Hasan bin Thabit's statement وَرُوحُ القُدْسِ لَيْسَ لَهُ كِفَاءُ which means ليس له نَظِير ولا مَثَيل

${ }^{22}$ Labib Muttaqin, 'Aplikasi Teori Double Movement Fazlur Rahman terhadap Doktrin Kewarisan Islam Klasik', Al-Manahij: Jurnal Kajian Hukum Islam, 7.2 (2013), 195-206 <https:// doi.org/10.24090/mnh.v7i2.564>.

${ }^{23}$ Mujjam Lughah al-Fuqahâ, Sumber: Mauqi' Yảsub tidak diterbitkan dalam Maktabah Syamilah. 
that is, there is no comparison and example. Means that the kafâah is meaningful comparison and examples. So when coupled with the word marriage it means the similarity or comparability between husband and wife in terms of heredity, position, religion, home. ${ }^{24}$

In the Arabic dictionary (Al-Wasit) explained that al-kafấah is the equality in strength and dignity. In the aspect of marriage, the equality of a husband and a wife in a position, religion and others. While in charity, the ability to carry out activities properly and professionally. ${ }^{25}$

According to Sayid Sabiq, kafâah means the same, equal and comparable. The meaning of kafâah or kufu' in marriage is that a man is equal to his future wife, equal in position, equal in social level, equal in wealth and character. ${ }^{26}$

Basically all definitions delivered by the Islamic Scholars are almost the same, but when the word al-kafâah does not go hand in hand with anything it has the meaning of equality (al-mumâtilah), equality (al-nadzîr) and ability (al-Qudrah). So that, the word of $k a f \hat{a} a h$ becomes a very interesting concept variable in building new theories in the context of Islamic family law. So, a question arises is that whether the concept of jurisprudence the definition of kafâah is already a patent, or there may be still a chance for new interpretation in this globalization era.

\section{Basic Law of Kafâ'ah}

Kafâah in Islamic law has clear legality both in Qur'an and in as-Sunnah, Islam asserts that the suitability of beliefs is the main basis in determining a life partner, as explained in the word of Allah, as followed:

And do not marry polytheistic women until they believe. And a believing slave woman is better than a polytheist, even though she

${ }^{24}$ Muhammad bin Mukram bin Mandzur al-Afriqi al-Mishri, Lisan Al-Arab, I (Beirut: Dar al-sadr, t.t).

${ }^{25}$ Ibrahim Mustafa, Al-Mujjam al-Wasith (Dar al-Da'wah, t.t).

${ }^{26}$ Sayyid Sabiq, Fiqh Sunnah, Jilid 7 (Bandung: Alma’arif, 1993), p. 36. 
might please you. And do not marry polytheistic men (to your women) until they believe. And a believing slave is better than a polytheist, even though he might please you. Those invite (you) to the Fire, but Allah invites to Paradise and to forgiveness, by His permission. And He makes clear His verses to the people that perhaps they may remember. (Al-Baqara: 221).

The kafâah is specifically emphasized in the hadiths below, which indicate the order to marry an equal woman. As the hadith narrated by Tirmidhi from Imam Ali ibn Abi Talib, Rosulullah said: O Ali there are three things when the time comes must not be postponed: prayer if it is already in time, the body if it is present to be blamed and the woman if there has come a partner who is sekufu 'with him'. The hadith narrated by al-Hakim, Ibn Majah, al-Baihaqi and al-Daruquthni, from Aisha, Rosulullah PUH: 'Choose women as a place to shed your sperms, look for those who are your partner' with you and marry them. The hadith narrated by al-Baihaqi and al-Daruquthni, from Jabir bin Abdillah AlAnshori, Rosulullah PUH said: 'You must not marry a woman except as sekufu'(equal) as you and do not marry her except with the guardian's permission ... 'The hadith narrated by al-Hakim and he validates it, Rosulullah PUH, said:It means: "Choose a woman as a container for spilling your cum, do not spill it on a place that is not sekufu or as equal as you'.

\section{Kafâ'ah in the History of Islamic Law}

Kafâah is one of the Islamic laws in Islamic marriage law. Each individual as a member of community has a description in mind of his/ her ideal form of the soul mate. The description is a reflection of the general view of the community where he lives. It is possible that the scope of personal worthiness (kafâah) in the community is within the framework of the public perception (perception), but maybe not.

In pre-Islamic Arab societies, the social order was built based on the family ties, ancestry (nasab), kinship, and ethnic ties. ${ }^{27}$ It is continuously

${ }^{27}$ Ira M. Lapidus, A History of Islamic Societes, Terjemahan Ghufron A. Masadi, Sejarah 
rooted beneath its cultures until Islam came. According to the writer that the kafâah is one of the Arabic traditions accommodated by Islam in order to maintain harmony in a family life since it has been practiced in a long time. However, there are some more principal changes in this kafâah law. Based on the pattern of accommodation, Islam has become a religion which is very tolerant of tradition, and maintain the social harmony of people, without radically making changes.

Islam brought by the Prophet Muhammad is a religion for all humans, bringing mercy to all nature. Islam does not distinguish one type of human from another human. The concept of egalitarian in Islam has changed social equality which was very dominant in Arab lands, with a new concept based on religious equality. ${ }^{28}$

However, arriving to the ideal value would require stages, and when Muslims are still improving themselves or in the initial phase of Islamic Tasyri. It is the time when the culture of pre-Islamic Arabic society, later on more or less has been accommodated by Rasulullah (Messenger of Allah) PUH. It is indeed as a form of flexibility in Islamic law, in building a better society, without using a contradictory pattern.

During pre-Islamic Arabic era, the matter of equality (kufî) was institutionalized in social life. For men, for example, the ideal marriage partner is young and comes from the noble descendants of the Arabs. It is very reprehensible to marry an Arab woman with a non-Arab man. Whereas, ideal matchmakers are men who are sweet, gentle and able to get along, generous and brave, noble but loyal. The man has the same social status, both in the degree of glory and fame. For example the daughters of the Quraysh tribe were only allowed to marry men who followed the tribe's religion. ${ }^{29}$

The structure of pre-Islamic Arab societies and families is not so different from when Islam was adopted. Stratification (levels) between one

Sosial Ummat Islam, (Jakarta: PT Raja Grafindo Persada, 2000), p. 3.

${ }^{28}$ Hammudah Abd al-'Ati, The Family Structure of Islam, Terj. Anshari Thayib, Keluarga Muslim (Surabaya: Bina Ilmu, 1984), pp. 107-8.

${ }^{29}$ Hammudah Abd al-Ati, The Family Structure of Islam, Terj. Anshari Thayib, Keluarga Muslim, p. 107. 
tribe and another remains, judging by the size of their social criteria. In accordance with these criteria, the size of each individual is determined by the basis of his religious virtues, it is whether they obey or not to their traditional values. For every Muslim, the value is still valid, only the measurement value is the righteous to Allah Almighty. According to the sunnah of the Prophet, the highest level is measured by the level of the righteous in religion. But he himself with his greatness had married a former slave of the Quraysh tribe. Marriage between someone from the upper level with slaves (the lowest level) may be difficult to understand. The example shown by the Prophet did not merely highlight the egalitarian spirit (the spirit of promulgation of the principle of political and social equality) of the Islamic religion. But, Islam does change the value of social equality (social equality) with a new concept that is based on equality in religion (religious equality).

Through the interaction between the Arab Muslims - as conquerors - with the native Kufah who were given the title of Mawali, inevitably the Arab Muslims were influenced and adopted it, especially in the case of marriage. As a result, a raised opinion that not allied Arab women with men who came from non-Arab tribes. This is one of the factors why Imam Abu Hanifa has special attention to the kafâah in marriage, even supporting the doctrine of social equality. What is very surprising is that he himself is not of Arab descent. So that, it can be ascertained that this social condition in Kufah, which many affect his ijtihad. As Reuben Levy said, there are very sharp classes of society, such as the mawali, Arabic, slave class, Ashraf class, and others. In fact, there are social classes that are seen from where they live, urban society is higher than the rural community. The existence of these classes has an impact on the insult of occupation. ${ }^{30}$

On the other hand, in the Medina community, the problem of $k a f a ̂ a h$ is not so prominent and it is not in line with the concept of Madinah scholars, because this region is far from the influence of Persian and Roman culture, besides its inhabitants are still dominated by Arabs

${ }^{30}$ Reuben Levy, The Social Structure of Islam (Jakarta: Pustaka Firdaus, 1986), pp. 65-75. 
and not mixed with many non-Arabs. So, it is naturally stated by Imam Malik who was in Medina then argued that the kafâa $a b$ was not in terms of heredity, wealth, position or profession in marriage.

Social class is an important fact of social reality, not just a theoretical concept, but also grouping them on: Firstly, wealth and income. Wealth and income are important determinants of social class due to its role in providing a picture of one's family background and his/her way of life. Secondly, occupation/profession. Occupation/profession is one of the best indicators to find out how someone lives. So, indirectly occupation/job is the best indicator to find out someone's social class. Thirdly, education. Social class and education influence each other at least in two ways, namely: 1) higher education requires money and motivation. 2) type and height of education achieved by one will affect the level of social class. Education is considered as more important for it will not only bear someone competencies in doing his job but also bear his mental changes, tastes, interests, goals, ways of speaking and changes in the overall of his way of life. In addition, the well-known social classes in society, there are also elements that make up the layers of society. The two elements are social status and role. ${ }^{31}$

\section{Demands for Equality and Competence in the Modern Era}

The changes occur in modern life are the effects of social change. The planned changes are best done for people who already have a desire to make changes, but are unable to do so. In such conditions, the community will immediately accept the changes made by the agent of change which accommodate the wishes of the surrounding community. It would be better before the planning was carried out, the agent of change would firstly make observations of the target communities, to find out their wishes and expectations, then adjust the existing plans accordingly. Social changes occur in a society within the community and occur due to factors that come from outside.

${ }^{31}$ Binti Maunah, 'Stratifikasi Sosial Dan Perjuangan Kelas Dalam Perspektif Sosiologi Pendidikan', Tảallum: Jurnal Pendidikan Islam, 3.1 (2015), 19-38 <https://doi.org/10.21274/ taalum.2015.3.1.19-38>. 
There are factors drive the way of change, namely: Contact with other cultures, Advanced formal education system, Attitude of respect for one's work and desires to progress, Tolerance for deviations that do not constitute offense, System open layers of society, heterogeneous population, community dissatisfaction with certain areas of life, orientation to the future, the value that humans must always strive to improve their lives.

By the changing occurs in the life of modern society, it will also change the demands of people's lives. If the past era of social status based on origins, class of people and wealth became something very important, in the modern era it experienced a very big change. When the community is structurally open, and does not see the origin, social stratification, but rather looks at achievement.

In addition, as the progress experienced by the community tends to be more professional, which will provide greater challenges to human life, both the State Institution. The demands of professionalism in the modern era would require several things as follows:

1. A new mindset and understanding of the importance of global competition, so people are required to think creatively in producing superior and competitive products.

2. State apparatus system should have the entrepreneurial nature as the engine of development.

3. The availability of bureaucrats as the public servants capable of designing economic development policy strategies

4. Technology excellence through the development of human resources produced by the new education system

5. The power of the private sectors in growing and becoming the prime movers and actors of the urban economy. ${ }^{32}$

${ }^{32}$ Heflin Frinces, Globalisasi Respon Terhadap Krisis Ekonomi Global (Yogyakarta: Mida Pustaka, 2009), p. 51. 
Through the extraordinary challenges of modernization, the demands of equality and social openness cannot be denied. As person will not be able to live by relying on his/her offspring, social status and even his/ her physical appearance.

In addition, the demands of equality in the modern world today which mostly urgent and needed in this era is competence. Competence is individual characteristics, the ability used in a consistent manner appropriately to achieve the desired performance. These characteristics include knowledge, skills, aspects of self-image, social motives, traits, thought patterns and ways of thinking, feeling, and implementation. ${ }^{33}$ According to Sanghi, ${ }^{34}$ competence is a process refers to various skilled performances and behaviors that must be applied in competent performances.

Wagner states seven skills needed in the 21 st century are (1) critical thinking and problem solving skills, (2) collaboration and leadership, (3) dexterity and adaptability, (4) initiative and entrepreneurial spirit, (5) able communicate effectively both orally and in writing, (6) able to access and analyze information, and (7) have curiosity and imagination. ${ }^{35}$

\section{Kafâ'ah's Contextualization in Fadzlurrahman's Double movement Theory}

\section{Reading the kafâ'ah of Present and the Past}

It is understood that current modern era as explained has been a lot of changes in terms of people's lives' behaviors, especially in implementing applicable laws and regulations. The change is very visible as the development of science and technology is ultimately leading to the digitalization of life.

${ }^{33}$ Dubois, D., Rothwell, J. W, Competency Based Human Resource Management (DaviesBlack Publishin, 2004).

${ }^{34}$ Sanghi, S, The Handbook of Competency Mapping: Understanding, Designing and Implementing Competency Models in Organization. (Sage Publication Pve, Ltd, 2007).

${ }_{35}$ Wagner, Overcoming The Global Achievement Gap (Online). (Cambridge: Harvard University, 2010). 
The most dominant changes in modern society are the demands of equality and competence. It is the mainstream changes in people lives, especially to Muslims. Due to the human mindset has been developing and containing of various consensus rules both in government and social institutions such as Human Rights. Equality is the most important issue today, as all human beings have the same rights before the law. This also happens in the case of marriage, that all humans have equality in getting a partner in life.

So that, the social strata were once dominated by individual social status, whereas in the modern era, it turns into professionalism in life. Social status does not survive when dealing with intellectual and competent achievements. Equality is the right of life, all have the right to be the best, especially in matters of marriage, without dealing with the symbol of social status but more on the quality of the bride and the bride groom.

It makes the kafâah rules included in the Jurisprudence books but not as a legal reference in marriage life. Even the rules of law set by the Muslim countries do not make it as a standard rule in regulating household life.

Then, it can be understood that the rules of the kafấah law are irrelevant in dealing with changes in life in this modern era. The irrelevance of this concept is of particular concern in this study, because Islamic law is flexible and even in every condition and time. So, it needs re-interpretation in understanding this law so that Islamic law can be implemented in all space and time.

\section{Al-Qur'an and As-Sunnah Responses}

Kafấah as a cultural product is not rejected by Islam, as Islamic wisdom is a perfect law (sharîah), it provides solutions to become more essential values, not only symbolic. So that, the cultural accommodation as a legal norm does not cause the followers (ummah) rejecting the contradictions but rather increasing the quality level. Some verses of alQur'an respond the existed social conditions which essentially numerous, contain general values and understood as principles of pure Islamic 
teachings and far from the social influence of people's lives. And this universal value can be implemented in all human life in every space and time.

a. Allah creates humans differently is to interact each other

O mankind, indeed We have created you from male and female and made you peoples and tribes that you may know one another. Indeed, the most noble of you in the sight of Allah is the most righteous of you. Indeed, Allah is Knowing and Acquainted. (Al Hujurat: 13)

In the above verse, Allah shifts the paradigm of society considers in social status as a difference to the quality of righteous as the standard. It shows that Islam is viewing the essence not the symbol. So that, it can be understood that Allah is highly to value human not because of his level of the entity but the essence of their righteous.

Righteous (taqwa) is the goodness of this religion, understood as the highest competence in human himself. By righteous, people will be able to live well, prosperous and happier. Moreover, in a married life, devotion becomes the most important competency to create a harmonious family.

b. The dignity standard is righteous

Indeed, the most noble of you in the sight of Allah is the most righteous of you. Indeed, Allah is Knowing and Acquainted. (Al Hujurat: 13)

c. Partner standards are a virtue value

Meaning: "Abominable women are for abominable men, and abominable men are for abominable women (too), and good women are for good men and men good ones are for good women (too)"

d. Rasulullah sets religion as the main standard compared to other material standards

"From Abi Hurairah ra that Rasulullah PBUH said," The woman was married because of four things: because of her religion, nasab, wealth and beauty. Then pay attention to your religion you will be safe " (Hadits Narrated by Bukhari Muslim)

e. Allah sees the hearts and deeds of His servants not the face and the physical 
It means "From Abu Hurairah, he said that the Prophet sallallaahu" alayhi wa sallam said, "Verily, Allah does not look at your forms and your treasures. However, Allah only looks at your hearts and practices. "(HN. Muslim no. 2564).

f. The order to accept the proposal of a man whose good at his character and religion

Abu Hurairah r.a reported that the Messenger of Allah had said:" If someone who is pleased with your religion and morals comes to you to marry your woman, then you should marry that person to your woman. If you don't do it there will surely be defamation on earth and great damage. " (Narrated by At-Tirmidhi no. 1084, Al-Imam Al-Albani's remembrance in Al-Irwa 'no. 1868, Ash-Shahihah no. 1022).

When the Companions asked, "O Messenger of Allah, do we still accept it even though there is something in this person that does not please us?" The Prophet answered this question by repeating the above hadith three times.

The response of al-Qur'an and as-Sunnah above clearly indicates that Islam does not see any symbol of social status in people's lives. In this response, Islam prioritizes the side of human qualifications rather than symbols of social status, it is suitable to the spirit of modernization which sees humans in terms of their qualifications, namely their competence.

\section{Generalization of Kafâ'ah Values in the Modern Era}

According to Sayid Sabiq, kafâah is interpreted as equal and comparable. The meaning of kafâah or kufu' in marriage is, a man which is equal to his future wife, equal in term of the position, equal in term of the social level, equal in terms of wealth and character. ${ }^{36}$

If the word al-kafâah is defined in linguistic context which is meant as equality (al-mumâtilah), equality (al-nadzîr) and ability (al-Ahliah). From this linguistic definition, there is one definition that has never been discussed, namely al-Ahliyah which means ability. While the essence of

${ }^{36}$ Sayyid Sabiq, Fiqh Sunnah, p. 36. 
al-kafâah is ability, although historically it is shown as a social symbol, but it shows someone's ability, because it is assumed that if the high social strata have high abilities as well.

Based on the above definition, the writer concludes relating many verses, which show the meaning of al-mumatsilah (equality) in surah al Mu'minun verse 52: "Actually, your Ummah is one Ummah". in the hadith of the Prophet Muhammad also said "A believer who is one to another believer is like a building whose parts are sturdy and solidify each other" (HN. Muslim). Equality. This is shown in the Surah al-Hujurat verse 13: "O mankind, indeed We have created you from male and female and made you peoples and tribes that you may know one another. Indeed, the most noble of you in the sight of Allah is the most righteous of you. Indeed, Allah is Knowing and Acquainted."

The meaning of al-nadzir (Equality), departs from the general values of the verse that the wife is a husband and husband are a couple. As in Surah al-Baqarah verse 187: They are clothing for you and you are clothing for them." Then that women have equal rights with their obligations, as mentioned in al-Baqarah verse 228: "And women have equal rights to their obligations in a manner that is more appropriate". This verse shows equality in rights and obligations understood by all humans. Furthermore, those who do good deed whether it is a male or female will enter paradise and those who do evil will be rewarded in hell, as mentioned in al-Mu'minun verse 40: "Whoever does an evil deed will not be rewarded but will be commensurate with the crime. And whoever does righteous deeds both male and female while he is in a state of faith, then they will go to heaven, they are given sustenance in it without reckoning".

The meaning of Al-Ahliyah lil Qiyam (Feasibility or Ability to do something), the principle of doing deeds in Islam is the ability and feasibility to carry out something. There is a rule about this that was revealed by Shaykh As Sa'di rahimahullah said in the verse of his poem: There is no obligation when unable to

Some meanings are discussed in the two verses above, namely; an obligation becomes a void when one incapable to do it. What is meant by capability, it is existed before and in progress. That is, an obligation can 
be failed if one does not have the ability before and when the obligation take place. Whereas, liability meant here is the liability demanded by Islamic law (shariah) with mandatory orders. The case of the sunnah is not included in this matter.

Some theorems that support this, including the words of Allah Ta'ala, It means "Fear God as much as you can" (Surah At Taghobun: 16). The Prophet sallallaahu 'alayhi wa sallam said, It means "If you are ordered to do something, then do what you can" (HN. Bukhari no. 7288 and Muslim no. 1337, from Abu Hurairah).

In the modern era, the definition of the term can be compiled by constructing the three words "mumatsilah, nadzir and abliabs" equation, equality and ability. So it can be explained that human nature is the same in term of the rights and obligations to Allah. As for, equivalently every human is equal in their status as human beings, no social stratification, education and so on. This has been explained in the principles of AlQur'an and as-Sunnah. Indeed, human beings are equated and equal, so that when al-kafâah is interpreted as conforming to the social, physical, economic status between partners, it is very contradictory with Islam, because the most noblemen before Allah, those righteous.

So, this principle is concluded that kafâa ah is only applied in religious areas, because it is related to devotion not to physical, material and social areas. If the al-kafâah is interpreted as conformity in the context of stratification, it is a tradition of Arab society which indeed until today has not totally been disappeared. They put the marriage standard based on the face quality, family class social status and economic standards.

As the meaning of abliyah or ability, according to the writer, it must be revealed as it is very suitable in modern life. A marriage must be conducted by a couple who are equally capable and have the ability to build a harmonious life in family affair. The good physical abilities namely the ability to care for themselves as the Prophet Muhammad said when he was asked: "who is the best woman? he replied: "The most pleasing if seen by her husband, obedient if ordered by her husband, and do not disregard the husband in himself and his wealth with what he hates" (HN. an-Nasa'I, valid) 
The essence of this hadith shows that household harmony can be realized by building physical nuances that are always beautiful, beautiful and vice versa for husbands. So that this ability has a profound effect on building a household.

Social abilities are also essentially needed in marriage, in building conducive situations between family of wife and husband, even the ability to educate children as a family continuer. This is symbolic in order to marry a woman who is full of love and has the potential of bearing many children as it will affect household harmony.

Economic capability is vital in a household affair, indeed in the era of the industrial revolution 4.0 has shaped humans as economic subjects, thus the economy becomes the dominant factor in harmony. The economic ability of the couple will form a good family, but otherwise will be easily damaged if it is economically weak.

Finally, the ability of religion, a quality area in which religion is universal, so Equality and the ability of a married couple in physical, social, economic and religious aspects in building a harmonious household happy in this world to hereafter will be fulfilled properly if one has mastered religion then he has sufficed himself and considered to be capable. Then, the ability of religion is essentially the ability in creed, worship, morals and socialization (muammalah), which is the universality of Islam.

Based on the arguments above, it can be reconstructed that the meaning of al-kafâah as a rule of law that is very relevant in the modern era. When equality has given up social boundaries, marriage does not look at status but is raised to the ability of a couple to get married. Even in the context of al-kafâah legislation, the most relevant is the legal basis for the certification of the bride and groom, as is the idea of the government through the ministry of religion.

\section{Conclusion}

The concept of al-kafâah in fiqh books initiated by the ulama is a very extraordinary concept in responding to the conditions of that era, but when faced with the complexity of the problems of the life of the people (Ummah) in this modern era, it is very irrelevant, as it has changed 
human standard of living. Formerly social status was a person's dignity and indicated ability, so marrying a social level was a must, because it was simple logic at the time. But with the changing times, in which the world has changed, the social barrier has been destroyed, the kafâa has changed from symbol to essence. And this is the substance of Islam, which makes religion the highest standard in kafâah.

The concept of al-kafâah is relevant to the life of the Islamic followers (Ummah). In the modern era, it is a concept that has been carried out by re-contextualization. In this case, the writer used the double movement theory of Fazlur Rahman, which took the moral values of the text of the $\mathrm{Al}-\mathrm{Qur}$ an after looking at current and past conditions. From the results of the re-contextualization, the definition of Equality and the ability of a married couple in the physical, social, economic and religious aspects in building a harmonious household in a happy world and hereafter. The definition is in accordance with the spirit of modernization which demands equality and competence in life, both will make the family more empowered and happy. Especially the meaning of ability should be focused in al-kafâah, ability in religion, economic ability, physical and social abilities.

\section{Bibliography}

Abdul Manan, Reformasi Hukum Islam Di Indonesia. Jakarta: Raja Grafindo Persada, 2006.

Abdurrahman, Kompilasi Hukum Islam Di Indonesia. Banjarmasin: Akademika Pressindo, 1992)

Assegaf, M. Hasyim, Derita Putra-Putri Nabi. Bandung: Remaja Rosda Karya, 2000.

Abu Zahrah, Muhammad, Al-Ahwâl al-Shakhsîyah. Mesir: Dâral-Fikr wa al-'Arabî, 1369.

Abd al-Ati, Hammudah, The Family Structure of Islam, Terj. Anshari Thayib, Keluarga Muslim. Surabaya: Bina Ilmu, 1984.

Abdul Aziz, Jamal, 'Teori Gerak Ganda (Metode Baru Istinbdt Hukum Ala Fazlur Rahman)', Hermenia, 6.No. 2 (2007), 329-49. 
Basri, Hasan. Merawat Cinta Kasih. Yogyakarta: Pustaka Pelajar, 1996. Barry, M, What Skills Will You Need to Succeed in the Future? Phoenix Forward (Online). University of Phoenix: Tempe, AZ:, 2012.

Dubois, D., Rothwell, J. W, Competency Based Human Resource Management. Davies-Black Publishin, 2004.

Fazlur Rahman, Islam and Modernity: Transformation of an Intelectual Tradition. Chicago \& London: The University of Chicago Press, 1982. —_, Kebangkitan Dan Pembaharuan Di Dalam Islam. Bandung: Pustaka, 2001.

Frinces, Heflin, Globalisasi Respon Terhadap Krisis Ekonomi Global. Yogyakarta: Mida Pustaka, 2009.

Hermanto, Edi, 'Implementasi Teori Tafsir Gerak Ganda Fazlur Rahman Pada Buku Ajar Al-Qur'an Dan Hadist', An-Nida', 41.1 (2018), 31-49.

H.S.A Al-Hamdani, Risalah Nikah (Hukum Perkawinan Islam I), Jakarta: Pustaka Amani, 1989.

Imam Suprayogo dan Tobroni, Metodologi Penelitian Social-Agama, Bandung: PT Rosda Karya, 1998.

Lapidus, Ira M. A History of Islamic Societes, Terjemahan Ghufron A. Mas'adi, Sejarah Sosial Ummat Islam, Jakarta: PT Raja Grafindo Persada, 2000.

Levy, Reuben, The Social Structure of Islam. Jakarta: Pustaka Firdaus, 1986. Malibary, Zainudin al-, Fathu Al-Mu’in. Beirut: Dar al-ihya'al Kitab al'Arabiyah, t.t.

Manzur, Jamal al-din Muhammad ibnu Mukarram al-Ansari al-, Lisan Al-Arabi. Mesir: Dar al Misriya, t.t.

Mustafa, Ibrahim, Al-Mu'jam al-Wasith. Dar al-Da'wah, t.t.

Maunah, Binti, 'Stratifikasi Sosial Dan Perjuangan Kelas Dalam Perspektif Sosiologi Pendidikan', Tảallum: Jurnal Pendidikan Islam, 3.1 (2015), 19-38 <https://doi.org/10.21274/taalum.2015.3.1.19-38>.

Mishri, Muhammad bin Mukram bin Mandzur al-Afriqi al-. Lisan AlArab, Beirut: Dar al-Sadr, t.t 
Muttaqin, Labib, 'Aplikasi Teori Double Movement Fazlur Rahman terhadap Doktrin Kewarisan Islam Klasik', Al-Manahij: Jurnal Kajian Hukum Islam, 7.2 (2013), 195-206 <https://doi.org/10.24090/mnh. v7i2.564>.

Nasution, Khoiruddin, Hukum Perkawinan I. Yogyakarta: Academia, 2004. Tazzafa, 2004.

Qaimi, Ali, Menggapai Langit Masa Denpan Anak. Bogor: Cahaya, 2001. Sibầ̂̀, Mustafa al-, Sharh Qânun Al-Ahwâl al-Shakhsîyah. Damaskus: TNP, 1385.

Syarief, Rachman, Kepemimpinan Transformasional Dan " $U$ Theory" Di Pendidikan Tinggi Dalam Menyongsong Pasar Bebas Asean. Metro: Universitas Muhammadiyah Metro, 2014.

Sanghi, S, The Handbook of Competency Mapping: Understanding, Designing and Implementing Competency Models in Organization. Sage Publication Pve, Ltd, 2007.

Sarwono, Sarlito Wirawan, Menuju Keluarga Bahagia 4. Jakarta: Bhatara Karya Aksara, 1982.

Sabiq, Sayyid, Fiqh Sunnah. Bandung: Al-Ma'arif, 1993.

S.N. Eisentadt, Modernization: Protest and Change. Prentice Hall Inc, Englewood Cliffs, 1966.

Soekanto, Soerjono, Sosiologi Suatu Pengantar, V, Jakarta: CV. Rajawali, 1985.

Sri Suhardjati dan Ridin Sofwan, Perempuan Dan Seksualitas Dalam Tradisi Jawa. Semarang: PSW IAIN Walisongo kerja sama dengan Gama Media, t.t.

Syukri, Ahmad, 'Metodologi Tafsir Al-Qur\&\#39;an Kontemporer dalam Pemikiran Fazlur Rahman', Kontekstualita: Jurnal Penelitian Sosial Keagamaan, 20.1 (2005), 37111.

Wagner, Overcoming The Global Achievement Gap (Online). Cambridge: Harvard University, 2010. 
Zaelani, Abdul Qodir, 'Pembaruan Hukum Keluarga: Kajian Atas Sudan - Indonesia', Al-'Adalah, 10.1 (2012), 331-342.

, 'Konsep Ta'aqquli Dan Ta'abbudi Dalam Konteks Hukum Keluarga Islam', Asas, 6.1 (2014), 46-56. 